\title{
SYVÄKASTELUN JA OLKIKATTEEN VAIKUTUKSESTA MAAVEDEN JÄNNITYKSEEN AITOSAVEN POHJAMAASSA
}

\author{
JOUKO VUORINEN \\ Maatalouden tutkimuskeskus, Maantutkimuslaitos, Helsinki
}

Saapunut 22. 1. 1958

Maaperän viljavuudessa on kosteussuhteilla oloissamme aivan ratkaiseva merkitys. Yksivuotisten kasvien kasvualustasșa huomio tällöin kiintyy ensisijassa multakerrokseen, jossa pääosa juuristosta sijaitsee. Hedelmätarhassa sen sijaan juuriston valtaosa on huomattavasti syvemmällä (7), joten maan viljavuuttakin on tutkittava ehkä toisella tavalla.

Kolmen viime vuoden aikana olen suorittanut tutkimuksia hedelmätarhan maaleikkauksen viljavuuden selvittämiseksi. Näiden tulokset näyttävät oikeuttavan useihin käytäntöä palveleviin päätelmiin. Vaikka tutkimus ei vielä ole kokonaisuudessaan valmis, esitän seuraavassa ennakkotietoina eräitä käytännön hedelmänviljelyyn mahdollisesti sovellettavia tuloksia.

Yhdessä tutkimuksen neljästä koetarhasta, nimittäin Koivulan puutarhassa Hirvensalossa, suoritettiin kasvukauden 1956 aikana aitosavimaan kosteuden mittaus- ja säännöstelytutkimus (6). Puuttumatta vielä sen yksityiskohtiin selostan tässä vain pohjamaan kosteussuhteiden muutoksia ja syväkastelun vaikutusta niihin.

Maan kosteuden seuraamiseen käytettiin n.s. tensiometrilaitteita, joilla mitataan sen imuvoiman suuruus (maaveden jännitys), jolla maassa oleva vesi on sidottu maahan $(5,4,1,3)$. Tämä riippuu huomattavasti sekä maalajista että maan kosteustilasta. Laitteisiin kuuluva elohopeavakuumimittari näyttää tämän voiman suuruuden alipaineena $(\mathrm{mm} \mathrm{Hg})$. Vastaavia laitteita käytetään (esim. USA:ssa ja Japanissa) myös käytännön palveluksessa puutarhojen ja kasvihuoneiden maan kosteuden seuraamisessa.

Maan kosteuden säätämiseksi oli e.m. tutkimuksessa (6) neljä erilaista käsittelyä: 1. mulloksella pidetty maa kastelematta ja 2. kasteltuna, 3. oljilla katettu puiden alusta (n. 2 m leveä katettu kaistale puurivin kohdalla) kastelemattomana ja 4. kasteltuna. Kastelu suoritettiin syväkasteluna Osmo VUorisen $(8,9)$ uudella syväkastelu-lannoituslaitteella noin puolen metrin syvyyteen. Kastelussa käytetty veden paine oli noin 2.5-4 ilmakehää ja kerralla annettu vesimäärä oli puuta kohti n. 7001 vastaten noin $40 \mathrm{~mm}: \mathrm{n}$ sadetta. 


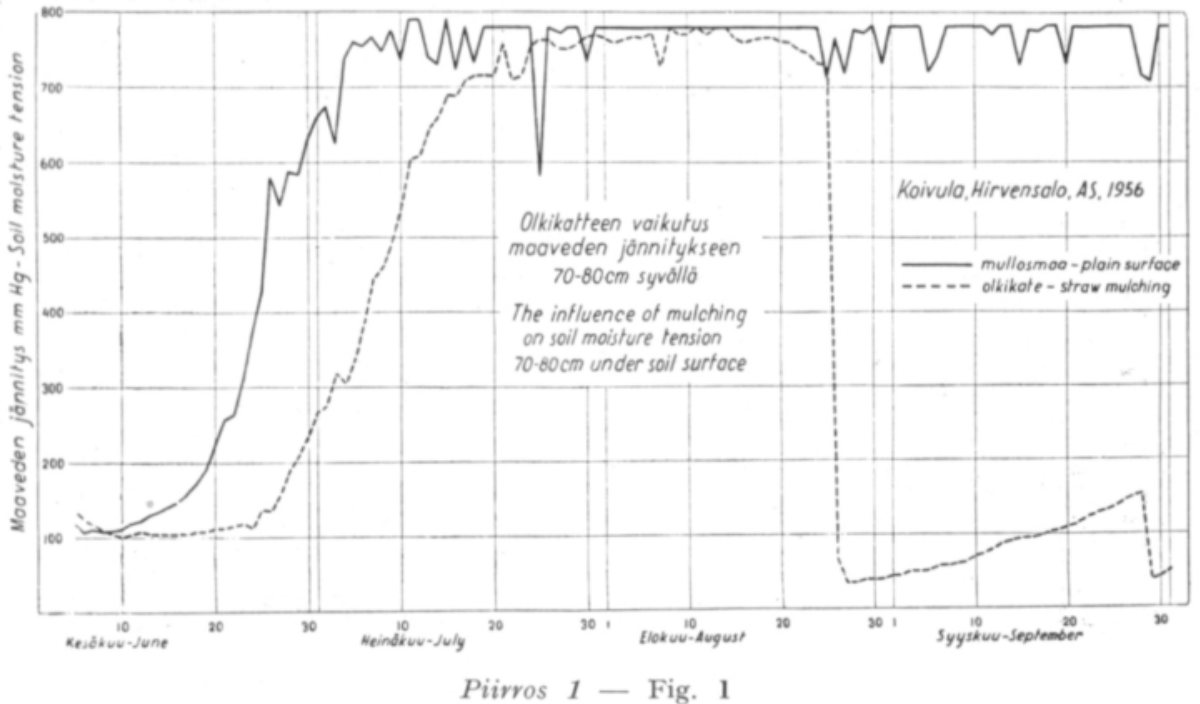

Tutkimuksen monista lukusarjoista esitän tässä vain kosteutta koskevat ja nekin vain pohjamaasta toisin sanoen tensiometreistä, joiden "tunteva" osa oli $70-80 \mathrm{~cm}: \mathrm{n}$ syvyydessä maan pinnasta lukien. Tulokset on esitetty piirroksina, joissa maaveden jännityksen vaihtelut nähdään alipaineen muutoksina $(\mathrm{mm} \mathrm{Hg})$. Pienet alipaineet osoittavat maan olevan märkää, ja maan kuivuessa alipaine kasvaa. Sataa millimetriä pienemmät paineet osoittavat tässä maalajissa (aitosavessa), että maassa on enemmän kuin $3 / 4$ jälellä siitä vedestä, minkä se enintään voi pidättää. Yli $700 \mathrm{~mm}: n$ alipaineet taas osoittavat, että jälellä on vastaavasti vain alle puolet tuosta enimmäisvesimäärästä. Kun kosteus tästä vielä pienenee, lisääntyy maan veteen kohdistunut vetovoima hyvin nopeasti ja niin suureksi, että kasvien veden saanti huomattavasti vaikeutuu (2). Kasvien vesitalouden kannalta on tärkein juuri se vesimäärä, mikä on otettavissa maasta alle yhden ilmakehän painetta vastaavalla voimalla.

Maan kosteussuhteiden tarkastelun jaan tässä kolmeen osaan. Piirroksessa 1 on esitetty olkikatteen vaikutus pohjamaan kosteuteen. Piirroksessa 2 on kastelun vaikutus mullosmaan ja piirroksessa 3 oljilla katetun alueen pohjamaan kosteussuhteisiin.

$\mathrm{K}$ a s t e le m a t t o m a s s a aitosavimaan koealueessa oli maaveden jännitys kesäkuun alussa noin $100 \mathrm{~mm} \mathrm{Hg}$ eli maksimivesimäärästä oli jälellä vielä n. 3/4. Kun avomulloksena tutkittavaksi tarkoitettu alue 5. 6. 56 vapautettiin olkikatteesta alkoi pohjamaan kosteudessa seuraava kehitys. Noin 10.6. 56 alkoi mullosmaassa nopea kuivuminen niin, että 4. 7. se saavutti yli $700 \mathrm{~mm} \mathrm{Hg:n} \mathrm{jännityksen.} \mathrm{Maksimi-}$ vesimäärästä oli tällöin siis jälellä enää vain n. puolet. Olkikatteen alla olevan pohjamaan kuivuminen alkoi vasta n. kaksi viikkoa myöhemmin (25. 6.) ja saavutti vastaavasti myöhemmin (17. 7.) $700 \mathrm{~mm}: \mathrm{n}$ jännityksen.

$\mathrm{M} \mathrm{u} 1 \mathrm{los} \mathrm{m}$ a a kohdalla kuivuminen jatkui sitten 4. 7.-24. 8. ilmeisesti hyvin voimakkaana. Tänä aikana mittari osoitti maksimilukemia jatkuvasti useamman viikon ajan eikä sen jälkeenkään elokuun lopun runsailla sateilla ole ollut sanot- 




Piirros 2 - Fig. 2

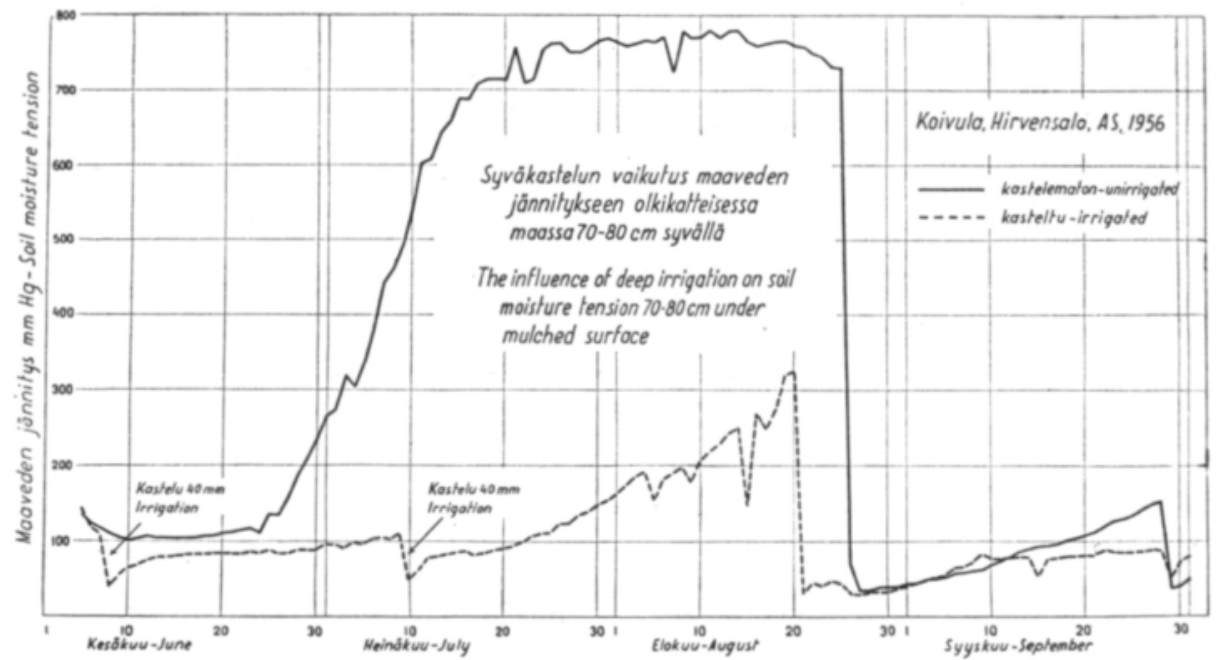

Piirros 3 - Fig. 3

tavaa vaikutusta maaveden jännitykseen pohjamaassa. Vielä lokakuun alussa jatkui sama kuivuus. O l k i k a t t e i s e $\mathrm{n}$ m a a n kosteus on ollut selvästi edellisestä poikkeava. Sen pohjamaan kuivakausi (17. 7.-26. 8) ei ilmeisesti ollut niin ankara kuin mulloksen alla, koska mittari on pysytellyt maksimilukemien alapuolella. Katetun maan suurempaa kosteutta osoittaa myös, että elokuun loppupäivien sateet alensivat maaveden jännityksen pohjamaassa yli kolmen viikon ajaksi alle $100 \mathrm{~mm} \mathrm{Hg}$. Sen jälkeenkin jännityksen nousu oli hyvin lievä ja laski taas syyslokakuun vaihteen sateiden vaikutuksesta alle $50 \mathrm{~mm} \mathrm{Hg}$.

Olkikate jatkoi kevätkosteuden aikaa noin kahdella viikolla. Se lyhensi myös muuten heinäkuun alussa alkaneen, koko kasvukauden kestäneen pohjamaan kuiva- 
kauden vajaaksi kuudeksi viikoksi, joka sekin oli ilmeisesti lievempi kuin mullosmaassa (piirros 1).

S y väk a s t e 1 u 11 a (piirros 2) saatiin m u 11 o sm a a n kevätkosteuden aikaa jatkettua (2 kastelukertaa à $40 \mathrm{~mm}$ ) noin kolme viikkoa kastelemattomaan verrattuna, mutta ennen kolmatta kastelua (24. 7.) ennätti maaveden jännitys kuitenkin nousta $700 \mathrm{~mm} \mathrm{Hg:in.} \mathrm{Kolmannen} \mathrm{kastelun} \mathrm{vaikutus} \mathrm{kesän} \mathrm{kuivakautena} \mathrm{oli} \mathrm{vain}$ n. kaksi ja puoli viikkoa, joten tämän kolmannen kastelun sijasta olisi tarvittu kaksi kastelua ennen elokuun lopun sateita. Nämä sateet eivät kuitenkaan mullosmaassa vaikuttaneet pohjamaan kosteuteen enempää kuin että sen jännitys jo kuukauden kuluttua jälleen oli $700 \mathrm{~mm} \mathrm{Hg}$.

S y väkas t e l u o lki k a t t e e n 1 äpi (piirros 3) piti kahdella kerralla (7. 6. ja 10. 7., á $40 \mathrm{~mm}$ ) pohjamaan kosteana koko kasvukauden ajan. Elokuun 20. päivään mennessä oli maaveden jännitys noussut vain n. $300 \mathrm{~mm} \mathrm{Hg:in,} \mathrm{mutta} \mathrm{laski}$ heti sateiden vaikutuksesta alle $50 \mathrm{~mm} \mathrm{Hg}$. Sen jälkeen jännitys ei lokakuun alkuun mennessä enää noussut yli $100 \mathrm{~mm} \mathrm{Hg}$. Kahdella kastelulla on pohjamaa pidetty riittävän kosteana ja kastelujen ajankohdat tuntuvat liiankin aikaisilta. Ensimmäinen kastelu olisi saanut olla ehkä kuukautta myöhemmin ja mahdollisesti se yksinäänkin vähän runsaampana olisi ollut riittävä.

Kesä-heinäkuun aikana annetulla syväkastelulla ei ole ollut vaikutusta mulloksella pidetyn hedelmätarhan pohjamaan syyskosteuteen nyt tutkitussa tapauksessa aitosavella. Sen sijaan pelkkä olkikate on selvästi pitänyt pohjamaan märkänä jo elokuun lopusta lähtien.

Edellä on lyhyesti esitetty edeltävänä tiedonantona tuloksia laajemmasta tutkimuksesta syväkastelun ja olkikatteen vaikutuksesta maan eri kerrosten kosteusja lämpöoloihin. Tässä esitetyillä tuloksilla on tarkoitus osoittaa vain, että syväkastelulla ja pinnan kattamisella voidaan tehokkaasti hallita pohjamaan kosteustilaa ja että tensiometrimittauksilla voidaan kastelun ajankohdat valita tarkoituksenmukaisesti. Mullosmaalla olisi kastelu ilmeisesti ollut suoritettava neljästi kahden viikon väliajoin, alkaen kesäkuun puolivälin jälkeen. Olkikatteen alla olisi kaksi kastelua riittänyt ja niiden suoritusajoiksi olisivat sopineet heinäkuun alku ja loppu.

Suomen olosuhteissa joudutaan tavallisesti kasvukauden lyhyyden lisäksi kärsimään liiasta kuivuudesta kasvukauden lämpimimpänä aikana. Sen vuoksi olisi meillä varottava keväällä maan liiallista kuivumista ja suojeltava ja lisättävä maan kosteutta erityisesti hedelmäviljelyksillämme kesäkuukausien aikana. Kasvukausien erilaisuudesta johtuen on varsinaisissa hedelmätalouksissa ilmeisesti ryhdyttävä maan kosteusoloja järjestelmällisesti seuraamaan.

(1) Aslyng, C. H. \& Kristensen, K. J. 1953. Investigations on the water balance in Danish agriculture. Kgl. Veter.- og. Landbohjsk. Årsskr. 1953: 44 - 90.

(2) FREI, E. 1953. Neue Untersuchungen über den Einfluss der Bodenfeuchtigkeit auf den Pflanzenertrag. Mitt.f.d. Schweiz. Landw. 1: 155-158. 
(3) Rasmussen, P. 1957. Vandbalance, meteoroligske og jordbundsfysiske målinger i frugtplantage ved forskellige kulturmetoder. Tidsskrift for planteavl, 61: 49-102.

(4) Richards, L. A. 1942. Soil moisture tensiometer materials and construction. Soil Sci. 53: $241-248$.

(5) Rogers, W. S. 1935. A soil moisture meter. J. Agric. Sci. 25: 326-343.

(6) VUorinen, J. 1957. Syvälannoitus ja -kastelu hedelmätarhassa. Hedelmälehti 4: 10 —11.

(7) $\rightarrow$ 1958. Omenapuun juuristosta. Summary: On the root system of apple-trees. Maat. tiet. aikak. 30: 41-57.

(8) Vuorinen, O. 1957. Hedelmäpuiden jaksottaissatoisuudesta. Hedelmälehti 4: $32-33$.

(9) $\longrightarrow$ 1957. Hedelmätarhan syväkastelusta ja syvälannoituksestå. Ibid 4: 59-61.

SUMMARY:

ON THE INFLUENCE OF DEEP IRRIGATION AND STRAW MULCHING ON THE SOIL MOISTURE TENSION IN HEAVY CLAY SUBSOIL

JOUKO VUORINEN

Agricultural Research Centre, Department of Soil Science, Helsinki

The author gives a preliminary report of a more extensive investigation concerning the moisture and temperature conditions in orchard soil profiles (6). This report concerns the studies made at Koivula orchard in South-west Finland.

The variation of subsoil moisture contents during the growing season in 1956 were measured by tensiometers (5. 4. 1.3). Fig. 1 indicates the effect of surface mulching with straw as compared to the effect of a plain surface on the moisture tension at $70-80 \mathrm{~cm}$. depth. The corresponding values in soils irrigated with a combined subsoil fertilizing and irrigation apparatus $(\mathbf{8 , 9}$.) are given in Fig. 2 (plain soil) and in Fig. 3 (straw mulched soil).

On the basis of the moisture contents of garden subsoils given in this paper it can be concluded that, in the relatively dry conditions of South-west Finland, four irrigation treatments (each corresponding to about $40 \mathrm{~mm}$. of precipitation) are required for preventing the subsoil moisture tension from rising up to $700 \mathrm{~mm} . \mathrm{Hg}$ in unmulched heavy clay soil (Fig. 2). The first treatment should be made during the latter part of June and the others at two-week intervals.

Using straw mulcing, the corresponding moisture content of orchard subsoil can be preserved if two treatments (at the beginning and at the end of June) are used (Fig. 3).

Straw mulching without irrigation (Fig. 1) prolonged the period of suitable moisture content of subsoil in spring for about two weeks and thus the dry period under straw cover continued for only about six weeks. On the contrary, the dry period under the plain surface commenced at the beginning of July and was still continuing at the beginning of October.

Because of the climatic conditions on Finland the growing season is very short, thus limiting the growth of plants. In addition, the plants usually suffer from droght during the warmest part of the growing season. Thus in our conditions the soils should not be drained too intensively in the spring, but conservation and increase of the soil moisture content during the summer months seems to be beneficial, especially in orchard soils. Because of the varying climatic conditions during different growing seasons systematical studies concerning moisture conditions in orchard soils should be planned. 